\title{
Customer Satisfaction in Using e-Travel: The Role of Self Efficacy, Trust, and Use
}

\author{
Nikos Joshua H. S. and Vera Pujani
}

\begin{abstract}
-the purpose of today business is not only the national business, but also the international business through e-business concept in particular e-travel contexts. E-travel is a tourism activity that done automatically through electronic technology and can be accessed from anywhere via its websites. The current paper presents to develop the conceptual framework of e-travel adoption model. Self-efficacy, trust and actual use are identified as influencing factors of customer satisfaction on e-travel. In this study, e-travel users as the research object..This theoretical framework explains how selfefficacy, trust and actual use affect the customer satisfaction on e-travel. The finding of this theoretical framework is selfefficacy, trust and use give positive impact to customer satisfaction. The afterward research would exanimated empirically using a survey method which employing PLS as a SEM software of analysis technique.
\end{abstract}

Index Terms-Travel, website, self efficacy, customer satisfaction.

\section{INTRODUCTION}

The new wave of change has been driven by the explosive growth of the Internet. The Internet is an international network of networks, all running TCP/IP (transmission control protocol/internet protocol), connected through a gateway and a router, and shares a common name and address space. It is based on an open architecture, and there is to facilitate resource sharing and collaboration among anyone, anywhere, at any time, which has connectivity.

The development of internet has change the world dramatically. By internet all of people in the world can search about the information that they want. One of the industries that have been directly affected by internet is tourism industry. In term of adopting and developing ICT applications, the tourism sector has become pioneer and as the top product or service categories that purchased through the internet stated by Garin-Munoz and Perez-Amaral [1]. With the rapidly increasing the popularity of internet, the travel website has been one of the most frequently visited by travel planners to get an online information stated by Choi, Lehto \& Oleary [2].According to Roney \& Ozturan, internet leading the innovation of business into a new era in the field of communication and changing transaction business systems. The market of products and services in the tourism industry relies heavily on information and has a highly segmented structure [3].

Tourism is an information intense industry stated by

Manuscript received May 29, 2014; revised July 23, 2014.

The authors are with Andalas University, Limau Manih Padang, Indonesia $25162 \quad$ (e-mail: joshua.nikos@aiesec.net, verapujani@yahoo.co.id).
Wethner \& Klein [4], therefore it is important to understand the changes in technologies and consumer behavior that influence the distribution and accessibility of travel related information. Tourism has been recognized as an information-based and information-intensive industry that's suited to information and communication technologies (ICTs). According to Davidson, over last 10 years, there has been an increase in research concentrating on the internet and small tourism enterprise. Tourism has long been the most one important components of the online commerce world, that has impact profoundly changed the structure of the industry. The role of online travel in increasingly gaining importance in today's travel and tourism industry. A travel industry without online travel or travel agents is quite unthinkable as it would result chaos and disruption in the industry [5]

Padang city, one of cities in Indonesia, that located in Sumatera Island which is in West Sumatera has potential tourism that tourist can visit. There is several beautiful tourism that tourist can visit which are several beaches and Padang is also famous as city of culinary. But since five years ago Padang has suffered several earthquakes and the biggest one happened on September, 30th 2009, because of that, Padang's tourism was collapsed. Not only from the national tourist but the international tourist also decided not to travel to Padang for a while.

How the factors of self-efficacy, trust and actual use influence customer satisfaction on E-travel website?

This paper is organized as follows. In the beginning, the review self-efficacy, trust, actual use and customer satisfaction are presented. The research hypoyhesis are proposed and continued by research methodology and results to answer the research questions. In the last section, the conclusion and implication are discussed.

\section{LITERATURE REVIEW}

\section{A. Self-Efficacy}

Self-efficacy refers to beliefs, expectation and self confidence that having by individual in their capability to perform a task [6]. According to Schwarzer, Mueller and Greenglass, these beliefs has related with optimistic behavior for being able to solve any varieties of challenging situation or task [7]. Self efficacy has been shown about the influence choice of whether to involve in a task, the effort that exposed to perform something and the persistence to accomplish something [8]. People with high or strong sense of efficacy are tending to more likely challenge themselves with difficult tasks and can motivate themselves intrinsically. This person will be brought high levels of effort in order to fulfill their commitments and they are 
more likely solving their problem by themselves than blaming the external factors. But people with low of self efficacy are tending to avoid the challenges and believe that difficult tasks and situation are beyond their capabilities. Self efficacy has related with the judgments of what one can do with whatever skills that they have [9]. The main idea of self efficacy is that the personal belief one has one's self is the basis of actions by individual [9].

Self Efficacy is another construct that would appear to hold as an important external factor of TAM. According to Pedersen, in the context of technology adoption, self efficacy can be viewed as an individual's self confidence in the ability to use an innovation to achieve a desired behavior [10]. Self efficacy should play an important role in high adoption of technology because consumers with higher self efficacy with respect to product would be expected to develop more positive attitudes towards it. Self efficacy on computer usage and in the context of management information system (MIS), confirm its influence on user's acceptance of technology [11]. Compeau and Higgins developed and tested a measurement of computer self efficacy, their research examined about the relationship between self efficacy, the environment and IT usage [12]. According to Compeau and Higgins, research showed that self efficacy as a mediator between environmental variables and outcomes expectations as well as actual usage [12].

According to Bandura, there are four major sources of self efficacy. First, Mastery Experiences; performing a task successfully will impact to strengthens the sense of self efficacy. However, unsuccessfully task or challenge can undermine and weaken self efficacy [13]. Second, Social modeling, by seeing people around you completing their task successfully is impact to increase the sources of self efficacy [13]. Third, Social persuasion- people could be persuaded to believe that they have their own skills and capabilities to be succeed. When someone said something positively and motivating us, it will be helped you to achieve a particular goals Getting verbal encouragement from others helps people to reduce their self-doubt and instead of focusing on giving the task on hand with the best effort [13]. Fourth, psychological responses- the feeling of person about their personal abilities in some situation can be predicted by moods, emotional states, physical reactions and stress level

\section{B. Actual Use}

A strong productivity orientation typically will characterize as technology adoption (usage) decisions [14]. In TAM, similar to TRA, a belief's of individual will determine the attitude toward using the system and, then intention to develop to use the system [14]. So, this intention influences the decision of actual system usage. Studies by Davis, Bagozzi and Warshaw, TAM is the proficient of explaining users behavior crossways of a broad range of end user computing technologies, alongside both parsimonious and hypothetically justified [15].

The use of E-travel is the activities that user has decided to use the website to search something about travel itself. By using E-travel, the user can be easy to know more about what they are going to find in the website because all of things about travel will be on it.
Actual system refers to ('how often') and the volume of system use ('how much') by the user [14]. Davis asserts that one's behavioral intention influences actual system usage. Technology Acceptance Model (TAM) has earlier postulated that two beliefs, known as the perceived usefulness and perceived ease of use, determine the attitudes of people toward using a particular system and such attitude together with PU and then will determine use intention and furthermore, this would lead to the actual use of the system [14].

\section{Trust}

As in defining trust, there is no agreed description of how trust is determined. Studies by Jones and George, argue that people's values, attitudes, moods and emotions interact will help the initiation, growth and evolution of trust [16]. Trust is also the willingness of a party to believe others party action based on the expectation that they will perform a particular action properly, irrespective of the ability to monitor or control the other party [17]. Trust is crucial factor in affecting relationship commitment and customer loyalty. By affecting the customer's perception of agreeing in values with service provider, trust influences the loyalty and such value agreeing is related to the customer's satisfaction and loyalty significantly. Trust as an element of customer loyalty has an influence on building customer loyalty [18].

According to Garbarino and Johnson, trust is the most widely examined and confirmed constructs in the relationship marketing research. Trust commonly discussed that have-related with behavioral intentions in E-commerce include sharing personal information, making a one time or repeating purchase, or acting on information provided by an e-vendor [19]. In consonance with the definition of trust adopted by Gefen, this study defines trust is a set of specific beliefs dealing with integrity- trustee honesty and promise keeping- a trustor believe that a trustee makes good faith agreements, tells the truth, acts ethically, and fulfills promises. Benevolence- is the extent to which a trustee is believed want to do good a trustor . Competence - ability of trustee to do what trustor needs [20]. Mcknight and Chervany presented other characteristic, predictability. Trust must go beyond predictability because one does not trust the other party who is highly predictability it will able to ignore the others need and act based in self interested fashion [21].

\section{Customer Satisfaction}

During the last four decades, satisfaction as one of has been considered the most crucial theoretical as well as practical issues for most marketers and customer researchers [22]. Satisfaction is response of emotional from customer when evaluating the expectation about the service with the actual performance perceptions. Satisfaction is important to the individual consumer because it reflects a positive outcome from the outlay of scarce resources and/or the fulfillment of unmet needs [23]. By having well in customer satisfaction it means that the business already success to fulfill the customer's need and it means the company have a good in research and segmenting the market. Studies by Roberts-Lombard define customer satisfaction as the degree to which performance of business's product or service matches up to the expectation of customer [24]. A higher 
level of customer satisfaction is tending to increase the customer loyalty, reducing price elasticity, insulating current market share from competitors, lower transaction costs, reducing the costs of failure and attracting new customers and develop image of organization in the marketplace [25].

Finally, five hypothesis are developed for this research.

Hypothesis 1: Self efficacy influence use of E-travel website

Hypothesis 2: The use if website influence trust in using E-travel website

Hypothesis 3: The use of website influence customer satisfaction in using E-travel website

Hypothesis 4: Trust influence customer satsifaction in using E-travel website.

\section{RESEARCH METHODOLOGY}

In this research will use quantitative research model which will exam the relationship among the variables. Quantitative research design had been selected in order to find out the appropriate answers to the research questions and to test the hypotheses [26].

Population refers to the entire group of people, events, or things of interest that the researcher wishes to investigate [26]. The population of this research is all customers in the two travel agent, they are Pelangi Holiday and Padang Indah Tour, Padang, West Sumatera.

\section{RESULT}

Questionnaires were distributed via online. The respondent taken from the travel agent information, where they are the customers of the travel agent. And also, we distributed the questionnaires to the people who ever open the travel agent website.

This research use PLS software to test the instrument validity of indicators in every variable that used. The result of validity test is based on convergent validity and discriminant validity, where the indicator measured from the value of outer loading thorugh algorithm process. The indicators will be stated as valid if the value of outer loading more than 0.70 . but, for loading $0.50-0.70$ still can be accepted as long as the value of AVE and communality more than 0.50 [27].

\section{A. Validity Test}

After collecting the data, the first thing that is done is testing the validity or validity test. The researcher used smartPLS 2.0 in order to test the validity of each indicators of each variable. To measure the validity of data, the researcher considers the evaluation based on convergent validity and discriminant validity. Convergent validity is examining whether the indicators of each variable definitely measure its variables. It means convergent validity is measured based on correlation between score item and indicators (component score) with construct score.

This test is done by measuring the value of outer loading through algorithm process. The indicators will be valid if the value of outer loading is above 0.7 . However, if the value of outer loading is higher than 0.5 and less than 0.7 , it is still accepted as long as the value of AVE and Communality is higher than 0.5 [28]. In this study, the indicator which has less than 0.5 outer loading value will be removed and reestimate will be done. The Table 4.17 is the result of data processing by using smartPLS 2.0. This Table I shows the value of outer loading of self efficacy, trust, the use of Etravel and customer satisfaction.

\begin{tabular}{|c|c|c|c|c|c|c|}
\hline & $\begin{array}{c}\text { Customer } \\
\text { Satisfaction }\end{array}$ & $\begin{array}{c}\text { Self } \\
\text { Efficacy }\end{array}$ & Trust & Use & Ave & $\begin{array}{l}\text { Composite } \\
\text { Reliability }\end{array}$ \\
\hline SE1 & 0,414533 & 0,733691 & 0,438596 & 0,592625 & & \\
\hline SE10 & 0,534178 & 0,749959 & 0,495613 & 0,577266 & & \\
\hline SE11 & 0,486682 & 0,816865 & 0,411252 & 0,537563 & & \\
\hline SE12 & 0,420733 & 0,755892 & 0,411874 & 0,500523 & & \\
\hline SE2 & 0,407879 & 0,772325 & 0,463333 & 0,534006 & & \\
\hline SE3 & 0,378049 & 0,668531 & 0,366296 & 0,550718 & 0,566142 & 0,923414 \\
\hline SE4 & 0,397787 & 0,772209 & 0,395894 & 0,595069 & & \\
\hline SE5 & 0,450593 & 0,767645 & 0,503783 & 0,484543 & & \\
\hline SE6 & 0,499734 & 0,809708 & 0,481056 & 0,482613 & & \\
\hline SE7 & 0,443866 & 0,761050 & 0,429580 & 0,498464 & & \\
\hline SE8 & 0,450260 & 0,727311 & 0,487130 & 0,517842 & & \\
\hline SE9 & 0,441937 & 0,679343 & 0,427477 & 0,428093 & & \\
\hline ST1 & 0,874795 & 0,527603 & 0,694489 & 0,467027 & & \\
\hline ST2 & 0,922313 & 0,528076 & 0,673037 & 0,512327 & 0,800841 & 0,923414 \\
\hline ST3 & 0,886903 & 0,526851 & 0,696227 & 0,457379 & & \\
\hline TR1 & 0,521284 & 0,465779 & 0,735850 & 0,426949 & & \\
\hline TR2 & 0,647053 & 0,436891 & 0,812876 & 0,422329 & 0,638182 & 0,875635 \\
\hline TR3 & 0,557499 & 0,475884 & 0,818065 & 0,419823 & & \\
\hline TR4 & 0,709996 & 0,500651 & $\mathbf{0 , 8 2 5 3 8 3}$ & 0,447192 & & \\
\hline USE1 & 0,389711 & 0,529842 & 0,288867 & 0,585540 & & \\
\hline USE2 & 0,391416 & 0,549113 & 0,410929 & $\mathbf{0 , 8 0 1 3 0 3}$ & 0,552125 & 0,829334 \\
\hline USE3 & 0,435295 & 0,525085 & 0,428460 & 0,804106 & & \\
\hline USE4 & 0,368541 & 0,483795 & 0,455917 & 0,759585 & & \\
\hline
\end{tabular}

$\mathrm{SE}=$ Self Efficacy, $\mathrm{ST}=$ Customer Satisfaction, TR=Trust, USE=Actual Use

\section{B. Reability Test}

Reliability test is done to find out the extent of the measurement tools have the accuracy and precision of measurement that are consistent over time. Reliability instrument on these research is determined from the value of composite reliability for each block of indicators on reflective invalid constructs. Rule of thumb value for cronbach's alpha and composite reliability must be greater than $0.7,0.6$ value though still acceptable [28]. The value of composite reliability can be seen in table I above.

\section{CONCLUSION}

This research has some implications for improving the understanding related with the relationship among self efficacy, trust and the use of e-travel website toward customer satisfaction. From the result, it proved all hypotheses in this research are accepted and the result supports the previous studies which are conducted by some researchers related with variable used in this research.

Using e-travel website will help travel agents to promote and offer their product easier to the customers. The more 
travel agents concern with the effectiveness of their travel website the more customers will use the website. In this research researcher found the self efficacy from user has significant influence to trust of user and trust of users has significant influence to the use of e-travel website and also the trust and use of e-travel website has significant effects to customer satisfaction.

\section{APPENDIX}

$\begin{array}{ll}\text { Items } & \text { Statement } \\ \text { SE1 } & \text { I am able to fill out a form online at the website travel } \\ \text { SE2 } & \text { I am able to open the page (links) available on the website of } \\ & \text { travel } \\ \text { SE3 } & \text { I am able to send e-mail through the website travel } \\ \text { SE4 } & \text { I am able to communicate through the website travel } \\ \text { SE5 } & \text { I am able to access things like travel website } \\ \text { SE6 } & \text { I am confident with my ability to use the website travel } \\ \text { SE7 } & \text { I am sure to use travel websites although there is nothing to } \\ & \text { teach } \\ \text { SE8 } & \text { I am sure I could solve the problem when using travel Web site } \\ \text { SE9 } & \text { I am sure to use travel website though never used it } \\ \text { SE10 } & \text { I am sure I can get information on travel website } \\ \text { SE11 } & \text { I have the skills needed to use a travel website } \\ \text { SE12 } & \text { I have the ability to get information on travel website } \\ \text { USE1 } & \text { I use travel websites to get information on tourism } \\ \text { USE2 } & \text { I use travel websites to get service (customer service) } \\ \text { USE3 } & \text { I make an order through the travel website } \\ \text { USE4 } & \text { I make payments through the travel website } \\ \text { TR1 } & \text { Travel Websites are not only looking for profit } \\ \text { TR2 } & \text { Travel Websites very care with customer } \\ \text { TR3 } & \text { Travel Website can be trusted/reliable } \\ \text { TR4 } & \text { Travel Websites can be predicted (expected) } \\ \text { ST1 } & \text { I am pretty satisfied with the travel website } \\ \text { ST2 } & \text { Travel Websites are already quite successful } \\ \text { ST3 } & \text { Travel Websites are in accordance with my expectations }\end{array}$

\section{ACKNOWLEDGMENT}

The authors are grateful to University of Andalas, Indonesia and Minister of Indonesian Higher Education (Dikti-DP2M) for giving the financial support of this research as International Research Collaboration grant and scientific Publication 2012 and 2013.

\section{REFERENCES}

[1] T. Garin-Munoz and T. Perez-Amaral, Internet Purchases of Specific Products in Spain, 2009.

[2] S. Choi, X. Y. Lehto, and J. T. Oleary, "What does the consumer want from a DMO Website? A study of US and Canadian tourists' perspectives," International Journal of Tourism Research, vol. 9, pp. 59-72, 2007.

[3] S. A. Roney and M. Özturan, 2006, "A content analysis of the web sites of Turkish travel agencies," International Journal of Tourismand Hospitality Research, vol. 17, no. 1, pp. 43-54, 2006.

[4] H. Werthner and S. Klein, Information Technology and Tourism: A Challenging Relationship, Vienna: Springer, 1999.

[5] A. Davidson, S. Burgess, and C. Sellitto, "An investigation of SMTE web site usage in Australia: implications for e-commerce adoption and planning processes," in Global Electronic Business Research: Opportunities and Directions, N. Al-Qirim, Ed. Idea Group Publishing: Hershey, PA, pp. 88-113, 2006.

[6] A. Bandura, "Multifaceted impact of self-efficacy beliefs on academic functioning," Child Development, vol. 67, pp. 1206-1222, 1996.

[7] R. Schwarzer, J. Mueller, and E. Greenglass, "Assessment of perceived general self-efficacy on the Internet: Data collection in cyberspace," Anxiety Stress and Coping, vol. 12, pp. 145-161, 1999.

[8] T. Bouffard-Bouchard, "Influence of self-efficacy on performance in a cognitive task," The Journal of Social Psychology, vol. 130, pp. 353-363, 1990

[9] J. Barling and R. Beattie, "Self-efficacy Beliefs and Sales Performance," Journal of Organizational Behavior Management, vol 5, pp. 41-51, 1983.
[10] P. Pedersen, "Adoption of mobile internet services: An exploratory study of mobile commerce early adopters," Working Paper, 2003.

[11] V. Ventakesh, "Determinants of perceived ease of use: integrating control, integrating motivation, and emotion into the technology acceptance model," Information Systems Research, vol. 11, no. 4, pp 342-365, 2000.

[12] D. R. Compeau and C. A. Higgins, "Computer self-efficacy: Development of a measure and initial test," MIS Quarterly, vol. 19, pp. 189-211, 1995.

[13] A. Bandura, Self-Efficacy: The Exercise of Control, New York: Freeman, 1997.

[14] N. K. Juliet, "Perceived usefulness, perceived ease of use, behavioral intention to use and actual system usage in centenary bank," Mastergraduate dissertation, Master of Science of accounting and finance of Makere University, Kamapala, 2011.

[15] F. D. Davis, R. P. Bagozzi, and P. R. Warshaw, 1989, "User acceptance of computer technology: a comparison of two theoretical models," Management science, vol. 35, no. 8, pp. 982-1003.

[16] G. R. Jones and J. M. George, "The experience of evolution of trust: implications for cooperation and teamwork," Academy of Management Review, vol. 23, pp. 531-546, 1998.

[17] R. C. Mayer, J. H. Davies, and F. D. Schoorman, "An integrative model of organisational trust," Academy of Management Journal, vol 20, no. 3, pp. 709-734, 1995.

[18] Y. Chen and J. Xie, "Cross-market network effect with asymmetric customer loyalty: implications for competitive advantage," Marketing Science, vol. 26, no. 1, p. 52, 2007.

[19] E. Garbarino and M. S. Johnson, "The different roles of satisfaction, trust and commitment in customer relationships," Journal of Marketing, vol. 63, pp. 70-87, 1999.

[20] D. Gefen, E. Karahanna and D. W. Straube, "Trust and TAM in online shopping: an integrated model," MIS Quarterly, vol. 27, no. 1, pp. 1-40, 2003.

[21] D. H. McKnight and N. L. Chervany, "What trust means in ecommerce customer relationships: an interdisciplinary conceptual typology," Management Science, vol. 46, no. 2, pp. 186-204, 2000.

[22] A. Jamal, "Retail banking and customer behavior: a study of self concept, satisfaction and technology usage," International Review of Retailing, Distribution and Consumer Research, vol. 14930, pp. 357379, 2004

[23] W. O. Bearden and J. E. Teel, "Selected determinants of consumers satisfaction and complaint reports," Journal of Marketing Research $(X X)$, pp. 21-28, 1983.

[24] M. Roberts-Lombard, "Customer retention strategies implemented by fast-food outlets in the Gauteng, Western Cape and KwaZulu-Natal provinces of South Africa: a focus on Something Fishy, Nando's and Steers," African Journal of Marketing Management, vol. 1, no. 2, pp. 70-80, 2009.

[25] E. W. Anderson and C. Fornell, "A customer satisfaction research prospectus," in Service Quality: New Directions in Theory and Practice, R. T. Rust and R. L. Oliver, Eds. Sage Publications, Thousand Oaks, CA, pp. 241-268, 1994.

[26] U. Sekaran, Research method for business, New York: John Wiley \& Sons, Inc, 2003

[27] I. Ghozali, Structural Equation Modelling Metode Alternatif Dengan Partial Least Square (PLS), Semarang: Badan Penerbit Universitas Diponegoro, 2006.

[28] D. R. Cooper and P. S. Schindler, Business Research Methods, Edisi 10, Inc. New York: The McGraw-Hill Companies, 2008.

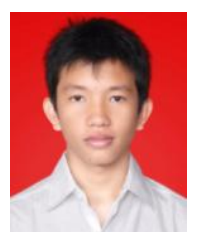

Nikos Joshua was born in Padang on November 9, 1992 $\mathrm{He}$ is an eight semester student at the Management Department in International Program, Economics Faculty of Andalas University, West Sumatera, Indonesia.

Nikos Joshua had internship to Philippine for environment project in 2011 and also went to Poland for internship about education, children and cultural project in 2013 and now working as a congress committee president of International Conference in Padang, West Sumatera which named GLS (Global Lead Summit), was in charged in National Supporting Team for AIESEC Hungary, AIESEC is International organization that run by college student and exist in 124 countries in entire world.

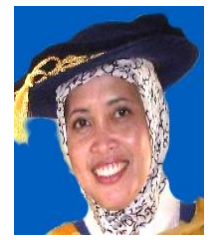

Vera Pujani is a senior lecturer in Economic Faculty, Andalas University. She finished her bachelor degree on management in Andalas University, Indonesia in 1993 she got the master degree at Management of Technology in Universiti Technologi Malaysia in 1997 and doctoral degree at e-commerce in Southern Cross University, Australia in 2008 